\title{
The Usefulness of Medial Sural Artery Perforator Free Flap for Head and Neck Reconstruction
}

\author{
Yuju Seo ${ }^{1}$ D , Sun-A Han ${ }^{1}$, Young Kang ${ }^{1}$, Young Ho Jung ${ }^{1}$, Soon-Hyun Ahn ${ }^{2}$, and Woo-Jin Jeong ${ }^{1}$ (D) \\ ${ }^{1}$ Department of Otorhinolaryngology-Head and Neck Surgery, Seoul National University Bundang Hospital, Seoul National University \\ College of Medicine, Seongnam; and ${ }^{2}$ Department of Otorhinolaryngology-Head and Neck Surgery, Seoul National University Hospital, \\ Seoul National University College of Medicine, Seoul, Korea
}

\author{
두경부 재건에서 내측 비복동맥 유리피판의 유용성

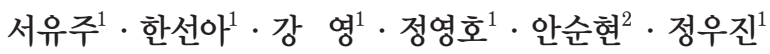 \\ 서울대학교 의과대학 분당서울대학교병원 이비인후과학교실, ${ }^{1}$ 서울대학교 의과대학 서울대학교병원 이비인후과학교실
}

\author{
Received August 25, 2019 \\ Revised October 13,2019 \\ Accepted November 1, 2019 \\ Address for correspondence \\ Woo-Jin Jeong, MD, PhD \\ Department of Otorhinolaryngology- \\ Head and Neck Surgery, \\ Seoul National University \\ Bundang Hospital, \\ Seoul National University \\ College of Medicine, \\ 82 Gumi-ro 173beon-gil, \\ Bundang-gu, Seongnam 13620, Korea \\ Tel $+82-31-787-7407$ \\ Fax $+82-31-787-4057$
}

E-mailsafar@snubh.org
Background and Objectives The ideal flap for head and neck reconstruction should be pliable, have sufficiently long pedicle and minimize donor defects. Anterolateral thigh free flap (ALTFF) and radial forearm free flap (RFFF) have been the workhorse flaps for head and neck reconstruction. However, ALTFF is too bulky and RFFF leaves a conspicuous scar on the donner site. Medial sural artery perforator free flap (MSAPFF) is a possible alternative, which has the benefit of thin RFFF and low donor site morbidity of ALTFF. Here, we evaluated for the first time the usefulness of MSAPF for head and neck reconstruction in Korean patients.

Subjects and Method We carried out a retrospective study of patients who underwent MSAPFF for head and neck reconstruction from October 2018 to July 2019 by retrieving their data from electronic medical records. Patient characteristics, flap characteristics, surgical outcomes, and complications of donor sites were analyzed.

Results Eight patients underwent MSAPFF reconstruction after head and neck surgery. The recipient sites were the following: the floor of the mouth, palate, tongue, the base of the tongue and nasolabial fold. The average median flap size was $34.1 \mathrm{~cm}^{2}$ (range $17.5-50 \mathrm{~cm}^{2}$ ), length 7.1 $\mathrm{cm}(5.0-10.0 \mathrm{~cm})$, width $4.7 \mathrm{~cm}$ (range 3.5-5.0 cm), and pedicle length $9.2 \mathrm{~cm}$ (range 8-10 cm) There was one flap failure because of pedicle arterial insufficiency. All donor sites were closed primarily without any complication.

Conclusion Based on the findings of this study, MSAPFF may be a new workhorse flap because it has thin, pliable tissue with low donor-site morbidity for head and neck reconstruction. Korean J Otorhinolaryngol-Head Neck Surg 2021;64(3):176-82

Key Words Head and neck neoplasm · Head and neck reconstruction · Medial sural artery perforator flap $\cdot$ Microvascular free flap.

\begin{abstract}
서 론
유리피판을 이용한 재건술은 원발부의 광범위한 제거 이 후 피부 이식이나 국소 피판으로 결손부를 재건하기 어려울

This is an Open Access article distributed under the terms of the Creative Commons Attribution Non-Commercial License (https://creativecommons.org/licenses/by-nc/4.0) which permits unrestricted non-commercial use, distribution, and reproduction in any medium, provided the original work is properly cited.
\end{abstract}

\begin{abstract}
정도로 결손부의 크기가 클 경우 필요한 재건술이다. 특히 구 강암 수술 이후의 재건은 얇고 유연한 피판을 요하며 발음, 저작, 기도 보호와 같은 구강의 기능을 가능한 보존하여야 하 기 때문에 고려할 것이 많은 재건술이다. ${ }^{1)}$ 두경부의 해부학적 및 기능적 특성을 고려한 이상적인 피판은 얇게 재단 가능하 면서도 유연하여 다양한 모양으로 재단할 수 있어야 하며 충 분한 혈관경의 길이를 확보하면서 공여부의 결손을 최소화하
\end{abstract}


여야 한다. ${ }^{2)}$ 주로 사용되는 대표적인 피판으로는 전외측대퇴 유리피판(anterolateral thigh free flap)과 요골전완 유리피 판(radial forearm free flap)이 있다.,4) 전외측대퇴 유리피판 의 경우, 긴 혈관경을 가진 충분한 부피의 조직을 채취 가능 하면서도 일차 봉합 및 술후 공여부의 합병증이 크지 않다는 장점이 있지만, 구강암 재건술에 이용하기에는 부피가 큰 경 우가 많으며 피판과 수혜부 간의 색상 불일치도 문제가 된 다. ${ }^{4-8)}$ 요골전완피판의 경우, 얇고 유연하여 구강암 재건에 적 합한 피판이지만, 공여부의 봉합을 위해 피부이식이 필요하 며 결손이 뚜렷하게 보이는 단점이 있다. ${ }^{9-11)}$ 내측 비복 동맥 천공지 유리피판(medial sural artery perforator free flap)은 전외측대퇴 유리피판과 요골전완 유리피판의 단점은 보완하 고 장점은 결합한 두경부 재건에 있어 이상적인 피판으로 여 러 문헌에서 보고되었다. ${ }^{10,12-16)}$ 하지만 한국인에서 두경부 재 건을 위한 피판으로서의 유용성 및 이식 결과에 대한 발표는 본 연구가 처음이다. 본 연구를 통해 한국인에서 두경부암 절 제 후 재건에 있어 내측 비복 동맥 천공지 유리피판의 유용 성과 술 후 결과에 대해 알아보고자 한다.

\section{대상 및 방법}

\section{대 상}

본 연구는 분당서울대학교병원에서 2018년 10월 2019년 7 월까지 시행된 비복 동맥 천공지 유리피판을 이용한 재건술 을 받은 8명의 환자를 대상으로 후향적으로 진행되었다(IRB
No. B-1908-561-110). 의무기록을 통해 환자들의 나이, 성별, 기저질환, 원발암의 병기, 이전 수술력 혹은 항암 방사선력을 조사하였다. 원발 부위 절제 후 결손부의 크기, 채취한 피판 의 크기, 혈관경의 길이, 혈관경과 문합한 수혜부의 동정맥, 공여부의 봉합방법을 조사하였다. 수술 후에는 피판 이식의 성공률, 수혜부와 공여부의 합병증을 평가하였다.

\section{내측 비복 동맥 천공지 유리피판의 수술 기법}

모든 수술은 전신 마취 하에 한 명의 두경부 외과의에 의 해 시행되었으며 피판의 크기는 원발부 결손부의 크기에서 약 $1 \mathrm{~cm}$ 의 절제연(safety margin)을 두고 도안되었으며 피판 거상 및 혈관경의 확인은 이전 여러 문헌에서 기술된 대로 시 행하였다(Fig. 1). 12,14,17) 고관절은 외전, 슬관절은 약간 굴곡 된 자세를 취하도록 한 이후 천공지의 위치를 확인하였다. 모 든 예에서 피판 거상을 하기 전에 도플러 초음파 프로브를 이용하여 천공지의 위치를 찾았다. 충분한 크기의 주요한 천 공지는 슬와주름(popliteal crease)의 중심에서부터 내측 복 사(medial malleolus)까지 그은 선에서 슬와 주름의 중심으 로부터 8 12 cm 사이에 위치해 있었다. 피판의 내측 경계부 터 조심스럽게 거상하여 종아리 후면의 중심선에서부터 근 육내 박리를 시작하였으며 피판 이식에 사용할 가장 큰 천공 지를 확인하였다. 이후 혈관경을 종아리 후부 근육들과 분리 하면서 슬와동맥(popliteal artery) 방향으로 박리하여 비복 근(gastrocnemius muscle)의 내측건 부근에서 채취하였다. 일반적으로 혈관경의 주행경로는 비복근 근섬유와 평행하므
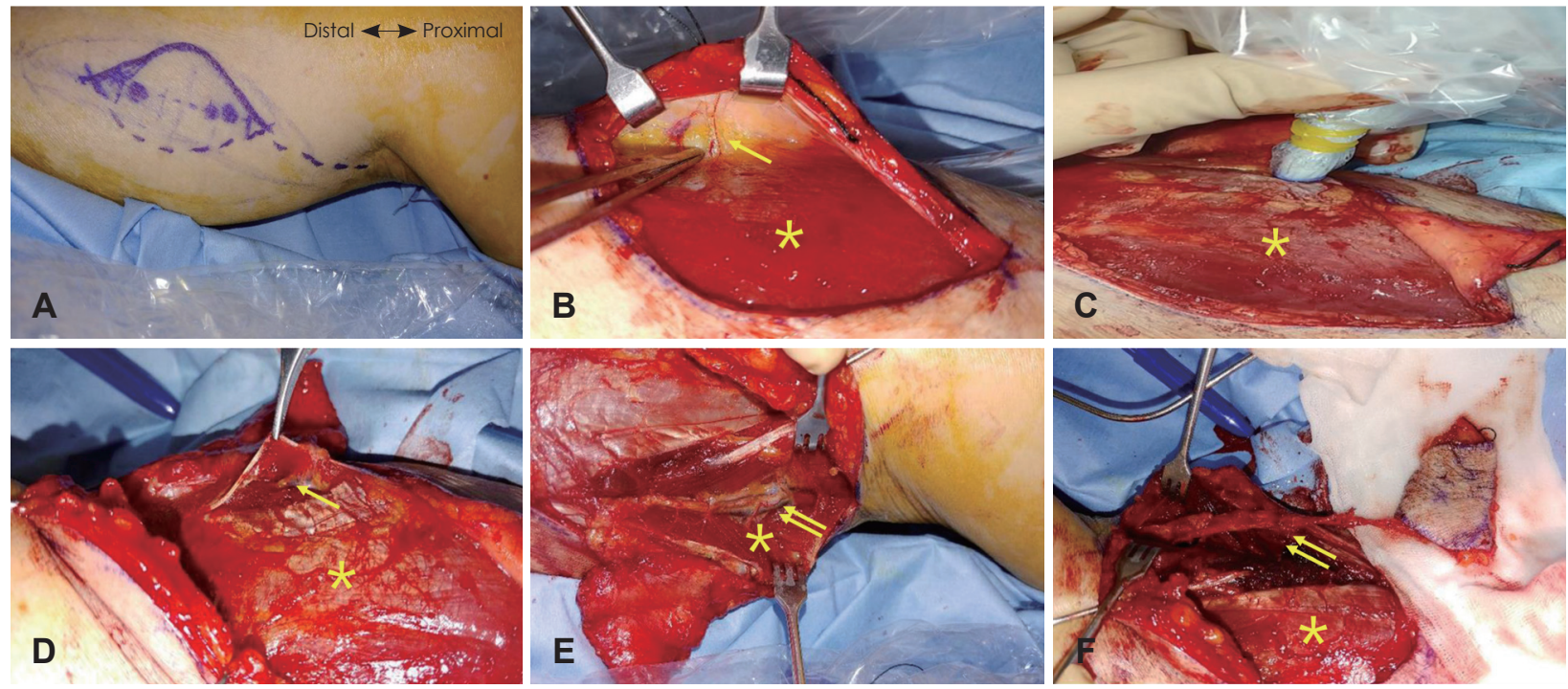

Fig. 1. The procedure of harvesting medial sural artery perforator flap (right side). A line was drawn from the middle of the popliteal crease to the medial malleolus (A). The first perforator was usually identified $8-12 \mathrm{~cm}$ along the previously described line (B). A hand-held doppler probe helped to identify the location of the perforators (C). The perforator was identified in a subfascial plane (D). After dissecting the muscle, the course of medial sural artery was exposed $(E)$. The pedicle was harvested at the level of the medial head of the gastrocnemius $(\mathrm{F})$. *: Medial gastrocnemius muscle, $\uparrow$ : perforator vessel, $\uparrow \uparrow:$ medial sural artery. 
로 비복근을 박리함으로써 혈관경을 쉽게 노출할 수 있었다. 정맥 유출로 venous output flow를 늘리기 위해 가능한 2개 의 동반정맥을 같이 채취하였으며 공여부는 모든 예에서 일 차 봉합되었다.

\section{결 과}

2018년 10월부터 2019년 7월까지 두경부 결손 이후 8예의 내측 비복 동맥 천공지 유리피판을 이용한 재건술이 시행되 었다. 대상 환자의 평균 나이는 61.6세(43 87세)로 전체 8명 중 남자가 6명(75.0\%), 여자가 2명(25.0\%)이었다. 1예에서(Table 1, case 8)에서 11년 전 원발 부위 절제술 및 비순피판을 이용한 재건술을 받은 수술력 및 원발부 재발로 방사선 치료 력이 있었으며 이외 환자들의 경우 이전 수술력 및 선행 항암 방사선화학치료를 받은 경우는 없었다. 대상 환자의 원발 부 위는 설부(tongue) 3예, 구강저(floor of mouth) 1예, 설기저 부(base of tongue) 1예, 경구개(hard palate) 1예, 연구개(soft palate) 1예, 비순주름(nasolabial fold) 1예 였다. 임상 병기는 T4aN1M0 1예, T3N3bM0 1예, T3NXMO 1예, T3NOM0 2예, T2NOMO 3예였다. 수술 후 1예에서 항암방사선치료, 2예에서 방사선치료를 받았으며 5예는 수술 이후 보조요법을 받지 않 았다(Table 1).
원발암 절제 후 결손부의 평균 크기는 $26.1 \mathrm{~cm}^{2}(16$ $\left.45 \mathrm{~cm}^{2}\right)$, 평균 길이는 $6.3 \mathrm{~cm}(4.0 \sim 9.0 \mathrm{~cm})$, 평균 너비는 $4.1 \mathrm{~cm}$ $(3.5 \sim 5.0 \mathrm{~cm})$ 였고, 피판의 평균 크기 $34.1 \mathrm{~cm}^{2}\left(17.5 \sim 50 \mathrm{~cm}^{2}\right)$, 평균 길이는 $7.1 \mathrm{~cm}(5.0 \sim 10.0 \mathrm{~cm})$, 평균 너비는 $4.7 \mathrm{~cm}(3.5 \sim$ $5.0 \mathrm{~cm})$ 이었다. 혈관경의 평균 길이는 $9.2 \mathrm{~cm}(8 \sim 10 \mathrm{~cm})$ 이었 다(Fig. 2). 동맥 문합은 7예(87.5\%)에서 안면동맥에, 1 예 (12.5\%)에서 설동맥에 시행되었다. 정맥 문합은 6예에서 두개 의 정맥에 시행되었으며 각각 4예에서 안면정맥동(facial vein plexus), 1 예에서 안면정맥과 설정맥, 1 예에서 안면정맥과 상 갑상선정맥에 문합되었다. 2 예에서는 각각 1 개의 안면정맥에 문합되었다. 모든 예에서 공여부는 일차 봉합되었으며 합병 증없이 회복되었다(Table 2). 전체 8 명의 환자 중 1 명의 환자 (case 1)에서 수술 후 이식부의 벌어짐(dehiscence)이 있었으 며, 혈관경 채취시 동맥부 부전(pedicle arterial insufficiency) 및 수술 이후 항암방사선요법을 받은 예였다. 1예(case 4) 에서 수술 후 5일째 피판의 탈피(flap desquamation)가 발생 하였으며 이식 실패로 판단하여 피판을 제거하였다. 전체 8명 환자의 수술 후 경과관찰 기간은 평균 6.6개월(1 8개월)이며 수술 후 공여부의 기능적 및 미용적 합병증은 모든 예에서 없었으며 피판 재건 이후 추가적인 중재가 필요할 정도의 수 혜부의 기능적인 결함을 호소하는 경우는 없었다(Fig. 3).

Table 1. Demographics and characteristics of patients

\begin{tabular}{|c|c|c|c|c|c|c|c|c|c|}
\hline Case & Age & Sex & Comorbidities & Prior treatment & Defect location & Operation & Stage & $\begin{array}{l}\text { Adjuvant } \\
\text { therapy }\end{array}$ & $\begin{array}{l}\text { Follow up } \\
\text { (months) }\end{array}$ \\
\hline 1 & $M$ & 55 & - & - & Floor of mouth & $\begin{array}{l}\text { FOM resection and } \\
\text { B) MRND }\end{array}$ & T3N3bM0 & CCRT & 10 \\
\hline 2 & $M$ & 57 & - & - & Hard palate & $\begin{array}{l}\text { Total palatectomy and } \\
\text { B) Level } 1 \text { SND }\end{array}$ & T3NOMO & PORT & 8 \\
\hline 3 & $M$ & 43 & - & - & Soft palate & $\begin{array}{l}\text { R) Palatectomy and } \\
\text { R) SOND }\end{array}$ & $\mathrm{T} 2 \mathrm{NOMO}$ & - & 8 \\
\hline 4 & $\mathrm{~F}$ & 79 & Poor controlled DM & - & Tongue & $\begin{array}{l}\text { R) Hemiglossectomy } \\
\text { and R) SOND, flap } \\
\text { removal on POD } 5\end{array}$ & T2NOMO & - & 8 \\
\hline 5 & $M$ & 83 & Asthma, HTN, CKD & - & Tongue & $\begin{array}{l}\text { L) Hemiglossectomy } \\
\text { and L) SOND }\end{array}$ & T2NOMO & - & 8 \\
\hline 6 & $\mathrm{~F}$ & 67 & $\begin{array}{l}\text { s/p bladder cancer, } \\
\text { HTN }\end{array}$ & - & Base of tongue & $\begin{array}{l}\text { L) BOT resection and } \\
\text { L) MRND, R) SOND }\end{array}$ & T4aNIMO & PORT & 5 \\
\hline 7 & $M$ & 40 & HTN & - & Tongue & $\begin{array}{l}\text { L) Hemiglossectomy } \\
\text { and L) MRND }\end{array}$ & T3NOMO & - & 5 \\
\hline 8 & $M$ & 69 & HTN, DM & $\begin{array}{l}\text { Excision } \\
\text { Nasolabial flap } \\
\text { RT }\end{array}$ & Nasolabial fold & $\begin{array}{l}\text { R) Nasolabial wide } \\
\text { excision }\end{array}$ & T3NXMO & - & 1 \\
\hline
\end{tabular}

DM: diabetes mellitus, HTN: hypertension, CKD: chronic kidney disease, s/p: status post, MRND: modified radical neck dissection, SND: selective neck dissection, SOND: supraomohyoid neck dissection, POD: postoperative day, CCRT: chemoradiation theraPy, PORT: postoperative radiotherapy 

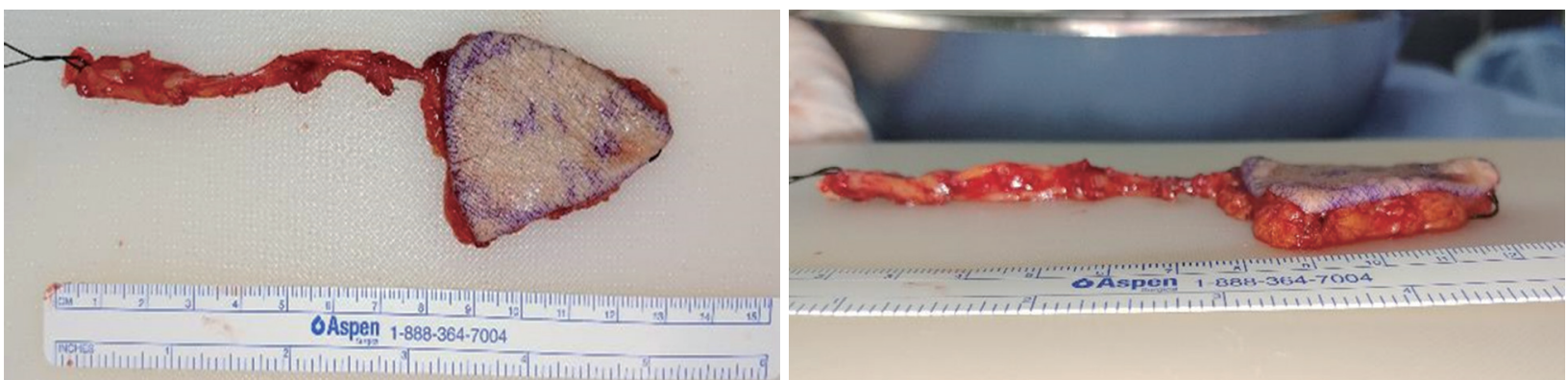

Fig. 2. The pedicle length and thickness of medial sural artery perforator flap. The average perforator length was $9.2 \mathrm{~cm}(8-10 \mathrm{~cm})$. The thickness and pliability of medial sural artery perforator flap were comparable to that of radial forearm free flap.

Table 2. Characteristics of medial sural artery perforator free flap

\begin{tabular}{|c|c|c|c|c|c|c|c|c|c|}
\hline \multirow{2}{*}{ Case } & \multirow{2}{*}{$\begin{array}{l}\text { Defect size } \\
(\mathrm{cm})\end{array}$} & \multirow{2}{*}{$\begin{array}{c}\text { Flap size } \\
(\mathrm{cm})\end{array}$} & \multirow{2}{*}{$\begin{array}{c}\text { Pedicle } \\
\text { length }(\mathrm{cm})\end{array}$} & \multirow{2}{*}{$\begin{array}{c}\text { No. } \\
\text { perforators }\end{array}$} & \multicolumn{2}{|r|}{ Anastomosis } & \multirow{2}{*}{$\begin{array}{c}\text { Flap } \\
\text { outcome }\end{array}$} & \multicolumn{2}{|l|}{ Complication } \\
\hline & & & & & Artery & Vein & & Recipient & Donor \\
\hline 1 & $7 \times 4$ & $8 \times 5$ & 8 & 1 & Facial a. & Facial v. plexus $(\times 2)$ & Success & $\begin{array}{c}\text { Dehiscence } \\
\text { (resolved) }\end{array}$ & - \\
\hline 2 & $9 \times 5$ & $10 \times 5$ & 9 & 1 & Facial a. & Facial v. & Success & - & - \\
\hline 3 & $6 \times 4$ & $7 \times 5$ & - & 1 & Facial a. & Facial v., Lingual v. & Success & - & - \\
\hline 4 & $5 \times 3.5$ & $5 \times 3.5$ & 9 & 1 & Facial a. & Facial v. plexus $(\times 2)$ & Failure & Flap desquamation & - \\
\hline 5 & $6.5 \times 4$ & $7 \times 5$ & 9 & 1 & Facial a. & Facial v. plexus $(\times 2)$ & Success & - & - \\
\hline 6 & $6 \times 4$ & $7 \times 5$ & 10 & 2 & Lingual a. & Superior thyroid v. Facial v. & Success & - & - \\
\hline 7 & $7 \times 4$ & $8 \times 5$ & - & 1 & Facial a. & Facial v. plexus $(\times 2)$ & Success & - & - \\
\hline 8 & $4 \times 4$ & $5 \times 4$ & 10 & 1 & Facial a. & Facial v. & Success & - & - \\
\hline
\end{tabular}

a: artery, v: vein

\section{고 찰}

두경부암의 재건을 위한 피판은 결손부의 크기, 위치, 수 혜부 및 공여부의 기능적 보존, 공여부의 합병증 등을 고려 하여 선택되어야 한다. 오랫동안 사용되어오는 두경부 재건 의 대표적 피판은 전외측대퇴 유리피판과 요골전완 유리피판 이다.,2) 요골전완 유리피판은 얇고 유연하며 긴 혈관경을 가 지고 있어 구강암의 재건에 적합한 피판이다. 하지만 대부분 의 경우에서 피판 채취 이후 공여부에 피부 이식이 필요하며 이식 이후에도 이식부가 뚜렷하게 눈에 띄는 미용적인 단점 및 수부의 주요한 동맥인 요골동맥(radial artery)을 희생하기 때문에 잠재적인 수부 허혈의 위험이 있다. ${ }^{18,19)}$ 전외측대퇴 유 리피판은 길고 충분한 크기의 직경을 가진 혈관경을 얻을 수 있으며 큰 부위의 결손도 재건이 가능하면서도 공여부의 결 함이 적어서 오랫동안 두경부 재건에 사용된 피판 중 하나이 다.,6) 하지만 구강암을 재건하기에는 부피가 크고 유연하지 못하며 피판을 얇게 재도안하는 과정에서 혈류(vascularity) 에 손상을 줄 수 있다. ${ }^{7,20}$ 내측 비복 동맥 천공지 유리피판은 얇고 유연한 피판을 얻을 수 있는 점은 요골전완 유리피판과 유사하지만 대부분의 경우에서 공여부의 일차봉합이 가능 하여 요골전완 유리피판에 비해 미용적 결과가 우수하다.21) $\mathrm{KaO}$ 등이은 두경부암의 재건에서 내측 비복 동맥 천공지 유
리피판과 요골전완 유리피판을 비교 시, 내측 비복 동맥 천공 지 유리피판이 요골전완 유리피판에 비해 더 우수한 공여부 의 기능 보존 및 미용적 결과를 보였다고 보고하였다. Daar 등 $^{21}$ 이 발표한 메타분석 논문에서 내측 비복 동맥 천공지 유 리피판의 공여부에 생긴 합병증은 $1.9 \%$ 로 이는 현재까지 보 고된 두경부 재건 이후 공여부의 합병증 중 가장 낮은 수치 중 하나이다.

Taufique 등은 내측 비복 동맥 천공지 피판의 혈관경의 평 균 길이는 $10.1 \mathrm{~cm}$ 로 이는 재건시 가장 많이 사용되는 안면 동정맥에 문합하기에 충분한 혈관경의 길이라고 보고하였 다. ${ }^{1,222)}$ 본 연구에서는 내측 비복 동맥 천공지 피판의 혈관경 의 평균 길이는 $9.2 \mathrm{~cm}$ 로 측정되었으며 전외측대퇴 유리피판 과 요골전완 유리피판에 비해 다소 짧은 경향이 있었다. 수술 전 하지 혈관조영 전산화단층촬영(lower extremity CT angiography)과 수술 중 도플러 초음파 프로브는 천공지의 위치 를 평가하는데 도움이 되며, 도플러 초음파 프로브를 이용한 천공지의 확인은 $92.8 \%$ 의 정확도를 보였다. 22,23$)$ 주요 천공지는 슬와주름(popliteal crease)의 중심선에서부터 내측복사(medial malleolus)까지 이은 선에서 슬와주름(popliteal crease) 으로부터 8 12 cm 거리에 있으며, 평균 2 8개의 천공지가 발 견되며 대개의 경우 우세 천공지(dominant perforator)가 있 다고 보고되었다. ${ }^{24,25}$ 본 연구에서는 천공지가 대부분 2 개 이 
하로 발견되었으며 다소 가늘었다. 피판의 도안은 가능한 천 공지가 피판의 중앙에 있도록 디자인하는 것이 이상적이며, 대개의 경우 1 개의 천공지로도 피판의 혈액 공급이 가능하 다. ${ }^{21)}$ Taufique 등은 내측 비복동맥 천공지 피판의 평균 두께
를 $8 \mathrm{~mm}$, Toyserkani 등은 평균 $5 \mathrm{~mm}$ 로 보고한 바 있다.,2) 전외측대퇴 유리피판의 평균 두께는 $11.55 \pm 4.38 \mathrm{~mm}$, 내측 비복동맥 천공지 유리피판은 $8.31 \pm 3.6 \mathrm{~mm}$ 로 내측 비복동 맥 천공지 유리피판이 전외측대퇴 유리피판보다 유의하게 얇
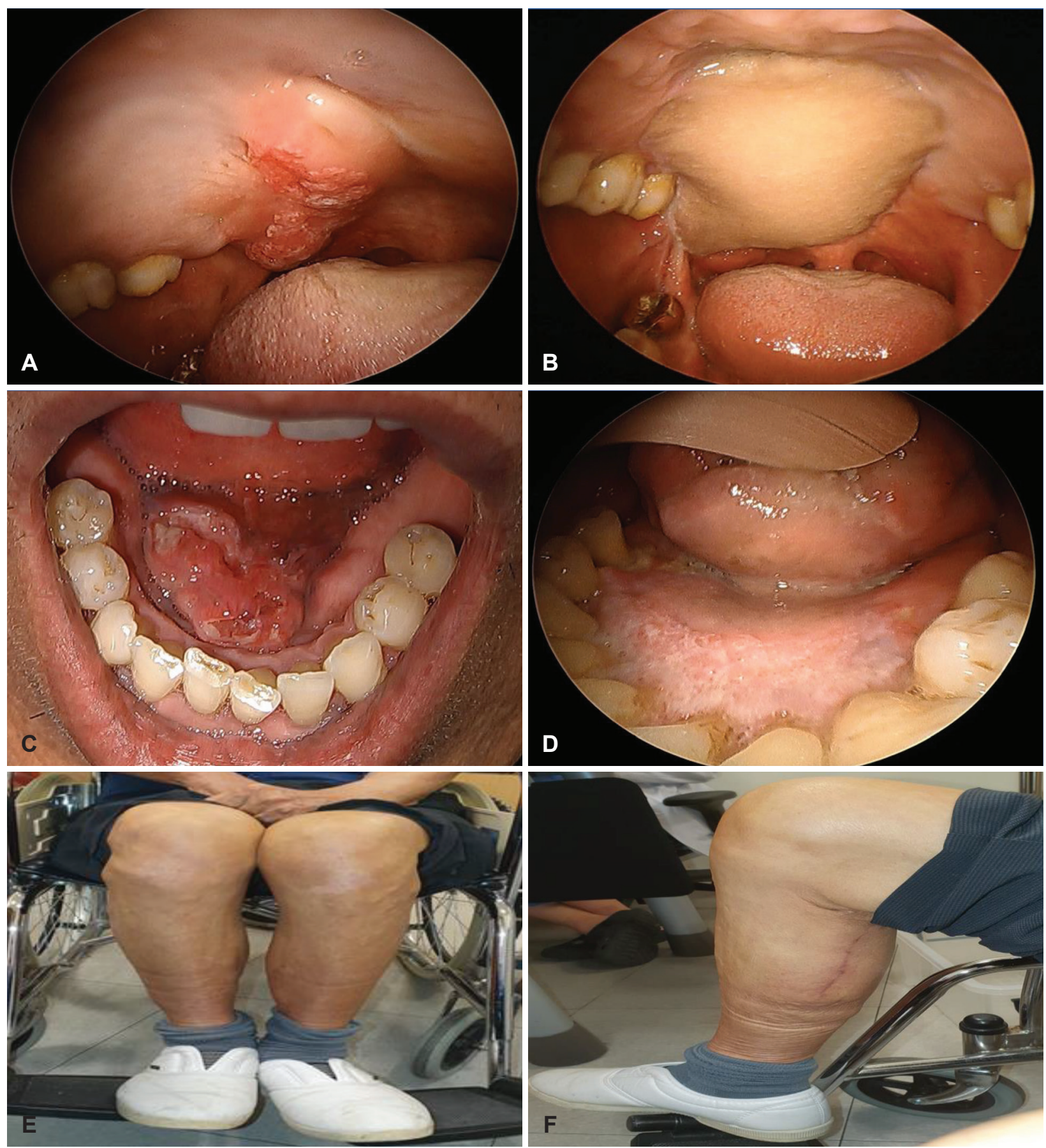

Fig. 3. The result of recipient site reconstruction and donor site after harvesting medial sural artery perforator free flap. Case 3 . Rt soft palate cancer (T2 stage), the photograph was taken 4 months after the reconstruction with MSAPFF showing a healthy transplanted flap (A, B). Case 1. FOM cancer (T3 stage), the photograph was taken 6 months after the reconstruction with MSAPFF showing a healthy transplanted flap $(C, D)$. The outcome of donor site after harvesting medial sural artery perforator free flap $(E, F)$. The photograph is the donor site of Case 5 on 8 months after surgery. Medial sural artery perforator free flap was harvested on right side. MSAPFF: medial sural artery perforator free flap, FOM: floor of mouth. 
다고 보고된 바 있으며, ${ }^{26)}$ 술자의 경험으로도 내측 비복 동맥 천공지 피판의 두께는 $5 \mathrm{~mm}$ 가량으로 보이며 전외측대퇴 유 리피판에 비해 얇았다. 이는 유연하여 안전하게 접힘이 가능 하여 중등도의 구강 결손 재건 이후 구강 기능을 회복하는데 이상적이다. ${ }^{21,27)}$ 내측 비복 동맥 천공지 유리피판은 요골전완 유리피판에 비해서 부피감이 있으면서 전외측대퇴 유리피판 보다 유연한 피판으로 중등도 결손의 구강암, 특히 구개(palate)와 구강저(floor of mouth) 같은 얇은 피판을 요하는 부 위에 유용하며 부피감을 요하는 상악부, 안면부의 재건에는 적합하지 않을 것으로 생각된다. 또한 요골전완 유리피판에 비해 미용적으로 우수한 장점이 있으나 천공지가 뚜렷하지 않은 경우가 있으며 혈관경을 채취하기까지 근육 내 박리과 정이 지루하고 시간이 많이 걸리는 단점이 있으므로 ${ }^{21)}$ 유리피 판 재건술에 익숙한 경험있는 술자가 사용하는 것을 권한다.

Taufique 등이 행한 메타분석에서 유리피판을 이용한 구 강암 재건에서 수혜부의 합병증 비교시, 내측 비복동맥 천공 지 유리피판 수혜부의 합병증율은 $14.3 \%$ 로 다른 유리피판의 경우(10.4 16.7\%)와 비슷하다. ${ }^{2,19,28)}$ 비복동맥 천공지 유리피 판의 이식 실패율은 $9.9 \%$ 로 전외측대퇴 유리피판과 요골전 완 유리피판의 실패율이 2 4\%인 것에 비해 높았다. ${ }^{1)}$ 이는 새 로운 피판이기 때문에 이식 결과에 대한 적은 샘플 수와 학 습곡선(learning curve)으로 인한 샘플 편견(sampling bias) 의 위험이 있지만, 현재까지 보고된 피판 이식 실패의 가장 흔한 원인은 정맥 유출로의 부전으로 보고되었다. ${ }^{1,21}$ 그러므 로 혈관 문합 과정에서 안전한 정맥 유출로를 확보하는 것이 권유되고 있으며, 단일 정맥 문합보다 표재성 정맥(superficial vein) 혹은 양측 동반정맥을 이용하여 2개의 정맥 문합 을 하였을 시 정맥 부전(venous insufficiency)이 덜 하였다 고 보고된 바 있다. ${ }^{1,29)}$ 대부분의 문헌에서 비복동맥 천공지의 동반 정맥이 문합에 이용되나 혈관경의 직경이 정맥 유출에 적절치 않다고 판단되면 표재성 정맥(superficial vein)이 대 안으로 사용 가능하다. ${ }^{14)}$ 본 연구에서도 가능한 두개의 정맥 문합을 하려고 하였으며 8예 중 6예(75\%)에서 두개의 정맥 문합을 하였다. 8예 중 정맥 유출로의 문제로 인한 피판의 실 패는 없었으나 피판 이식에 실패한 1예(Table 2, case 4)에서 는 혈관경이 매우 얇았으며 동맥 부전으로 인한 실패로 판단 되었다. 샘플 수가 적기는 하나 본 연구의 경험상 내측 비복 동맥 천공지는 다소 혈액량이 좋지 못한 경우가 있었으며 혈 관경의 직경 및 두께가 일정치 못했고 혈관경의 길이가 전외 측대퇴 유리피판과 요골전완 유리피판의 혈관경에 비해 다소 짧았다. ${ }^{21}$

과거 문헌들에서 피판의 너비가 $5 \mathrm{~cm}$ 이상일 경우 부분층 피부 이식(split-thickness skin graft)을 권한다고 보고되었
으나, ${ }^{14,30)}$ 2019년 발표된 비복동맥 천공지 유리피판에 대한 메 타분석에서 부분층 피부 이식을 시행한 공여부의 평균 결손 크기는 $97.6 \mathrm{~cm}^{2}(12.2 \times 8.0 \mathrm{~cm})$ 이었으며, 일차 봉합한 경우는 $44.5 \mathrm{~cm}^{2}(5.0 \times 8.9 \mathrm{~cm})$ 이었다. ${ }^{21)}$ 본 연구에서는 피판의 너비가 $10 \mathrm{~cm}$ 인 경우도 문제없이 공여부의 일차 봉합이 가능하였다.

이 연구는 대상 환자가 적으며 두경부 재건술에 대표적으 로 쓰이는 전외측대퇴 유리피판과 요골전완 유리피판과 직접 비교 분석을 하지 못한 제한점을 가지고 있다. 또한 단일 기 관의 단일 외과의에 의해 시행된 수술을 분석하여 이에 따른 선택 편견(selection bias)이 개입될 여지가 있다. 향후 다른 피판과의 직접 분석을 다룬 전향적인 연구가 필요하다. 하지 만 이 연구는 최초로 한국인의 두경부 결손부의 재건에 내측 비복 동맥 천공지 유리피판을 적용하고 그 특징을 분석한 점 에서 의의가 있다. 본 연구를 통해 내측비복 동맥 천공지 유 리피판은 중등도의 두경부 결손의 재건에 적절한 얇고 유연 한 피판을 얻을 수 있으면서 동시에 공여부의 미용적 성적이 우수한 방법임을 확인할 수 있었다.

\section{Acknowledgments}

None.

\section{Author Contribution}

Conceptualization: Woo-Jin Jeong. Data curation: Yuju Seo. Formal analysis: Yuju Seo. Investigation: Yuju Seo, Sun-A Han. Methodology: Yuju Seo, Woo-Jin Jeong. Supervision: Woo-Jin Jeong, Young Ho Jung, Soon-Hyun Ahn. Validation: Yuju Seo, Young Kang. Visualization: Yuju Seo, Young Kang. Writing_-original draft: Yuju Seo. Writing — review \& editing: Woo-Jin Jeong.

\section{ORCIDs}

Woo-Jin Jeong

Yuju Seo

https://orcid.org/0000-0001-8577-6964 https://orcid.org/0000-0003-3578-0505

\section{REFERENCES}

1) Toyserkani NM, Sørensen JA. Medial sural artery perforator flap: A challenging free flap. Eur J Plast Surg 2015;38(5):391-6.

2) Taufique ZM, Daar DA, Cohen LE, Thanik VD, Levine JP, Jacobson AS. The medial sural artery perforator flap: A better option in complex head and neck reconstruction? Laryngoscope 2019;129(6): $1330-6$.

3) de Bree R, Rinaldo A, Genden EM, Suárez C, Rodrigo JP, Fagan $\mathrm{JJ}$, et al. Modern reconstruction techniques for oral and pharyngeal defects after tumor resection. Eur Arch Otorhinolaryngol 2008; 265(1):1-9.

4) Genden EM, Jacobson AS. The role of the anterolateral thigh flap for pharyngoesophageal reconstruction. Arch Otolaryngol Head Neck Surg 2005;131(9):796-9.

5) Agostini T, Lazzeri D, Spinelli G. Anterolateral thigh flap thinning: Techniques and complications. Ann Plast Surg 2014;72(2):246-52.

6) Collins J, Ayeni O, Thoma A. A systematic review of anterolateral thigh flap donor site morbidity. Can J Plast Surg 2012;20(1):17-23.

7) Sharabi SE, Hatef DA, Koshy JC, Jain A, Cole PD, Hollier LH Jr. Is primary thinning of the anterolateral thigh flap recommended? Ann Plast Surg 2010;65(6):555-9. 
8) Alkureishi LW, Shaw-Dunn J, Ross GL. Effects of thinning the anterolateral thigh flap on the blood supply to the skin. Br J Plast Surg 2003;56(4):401-8.

9) Kruse AL, Bredell MG, Lübbers HT, Jacobsen C, Grätz KW, Obwegeser JA. Clinical reliability of radial forearm free-flap procedure in reconstructive head and neck surgery. J Craniofac Surg 2011;22(3):822-5.

10) Kao HK, Chang KP, Wei FC, Cheng MH. Comparison of the medial sural artery perforator flap with the radial forearm flap for head and neck reconstructions. Plast Reconstr Surg 2009;124(4): 1125-32.

11) Richardson D, Fisher SE, Vaughan ED, Brown JS. Radial forearm flap donor-site complications and morbidity: A prospective study. Plast Reconstr Surg 1997;99(1):109-15.

12) Chalmers RL, Rahman KM, Young S, Kennedy M, Endersby S, Adams JR, et al. The medial sural artery perforator flap in intra-oral reconstruction: A Northeast experience. J Plast Reconstr Aesthet Surg 2016;69(5):687-93.

13) Chen SL, Chen TM, Dai NT, Hsia YJ, Lin YS. Medial sural artery perforator flap for tongue and floor of mouth reconstruction. Head Neck 2008;30(3):351-7.

14) Choi JW, Nam SY, Choi SH, Roh JL, Kim SY, Hong JP. Applications of medial sural perforator free flap for head and neck reconstructions. J Reconstr Microsurg 2013;29(7):437-42.

15) Kim HH, Jeong JH, Seul JH, Cho BC. New design and identification of the medial sural perforator flap: An anatomical study and its clinical applications. Plast Reconstr Surg 2006;117(5):1609-18.

16) Song $X$, Wu H, Zhang W, Chen J, Ding X, Ye J, et al. Medial sural artery perforator flap for postsurgical reconstruction of head and neck cancer. J Reconstr Microsurg 2015;31(4):319-26.

17) Nugent M, Endersby S, Kennedy M, Burns A. Early experience with the medial sural artery perforator flap as an alternative to the radial forearm flap for reconstruction in the head and neck. Br J Oral Maxillofac Surg 2015;53(5):461-3.

18) Taghinia AH. Radial forearm flap. In: Wei FC, Mardini S, editors. Flaps and Reconstructive Surgery. 2nd ed. China: Elsevier;2017. p.525-40.

19) Genden EM, Wallace DI, Okay D, Urken ML. Reconstruction of the hard palate using the radial forearm free flap: Indications and outcomes. Head Neck 2004;26(9):808-14.
20) Ross GL, Dunn R, Kirkpatrick J, Koshy CE, Alkureishi LW, Bennett N, et al. To thin or not to thin: The use of the anterolateral thigh flap in the reconstruction of intraoral defects. Br J Plast Surg 2003;56(4):409-13.

21) Daar DA, Abdou SA, Cohen JM, Wilson SC, Levine JP. Is the medial sural artery perforator flap a new workhorse flap? A systematic review and meta-analysis. Plast Reconstr Surg 2019; 143(2):393e-403e.

22) He Y, Jin SF, Zhang ZY, Feng SQ, Zhang CP, Zhang YX. A prospective study of medial sural artery perforator flap with computed tomographic angiography-aided design in tongue reconstruction. J Oral Maxillofac Surg 2014;72(11):2351-65.

23) Zhao W, Li Z, Wu L, Zhu H, Liu J, Wang H. Medial sural artery perforator flap aided by ultrasonic perforator localization for reconstruction after oral carcinoma resection. J Oral Maxillofac Surg 2016;74(5):1063-71.

24) Dusseldorp JR, Pham QJ, Ngo Q, Gianoutsos M, Moradi P. Vascular anatomy of the medial sural artery perforator flap: A new classification system of intra-muscular branching patterns. J Plast Reconstr Aesthet Surg 2014;67(9):1267-75.

25) Kao HK, Chang KP, Chen YA, Wei FC, Cheng MH. Anatomical basis and versatile application of the free medial sural artery perforator flap for head and neck reconstruction. Plast Reconstr Surg 2010; 125(4):1135-45.

26) Akdeniz Doğan ZD, Çavuş Özkan M, Tuncer FB, Saçak B, Çelebiler Ö. A comparative clinical study of flap thickness: Medial sural artery perforator flap versus anterolateral thigh flap. Ann Plast Surg 2018;81(4):472-4.

27) Haughey BH, Taylor SM, Fuller D. Fasciocutaneous flap reconstruction of the tongue and floor of mouth: Outcomes and techniques. Arch Otolaryngol Head Neck Surg 2002;128(12):1388-95.

28) Soutar DS, McGregor IA. The radial forearm flap in intraoral reconstruction: The experience of 60 consecutive cases. Plast Reconstr Surg 1986;78(1):1-8.

29) Ichinose A, Terashi H, Nakahara M, Sugimoto I, Hashikawa K, Nomura T, et al. Do multiple venous anastomoses reduce risk of thrombosis in free-flap transfer? Efficacy of dual anastomoses of separate venous systems. Ann Plast Surg 2004;52(1):61-3.

30) Ives M, Mathur B. Varied uses of the medial sural artery perforator flap. J Plast Reconstr Aesthet Surg 2015;68(6):853-8. 